\title{
Effects of Anisakis Allergenic Proteins on Fish-Borne Food Safety Risks
}

ISSN: 2637-7659

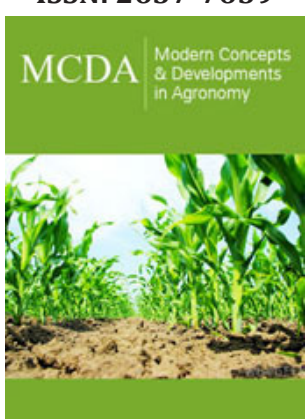

*Corresponding author: Shuze Tang, Department of Food Science and Engineering, Jinan University, Guangzhou, China

Submission: 些April 30, 2021

Published: 眥 May 17, 2021

Volume 8 - Issue 4

How to cite this article: Wenqi Du, Dongli Dong, Yi Tan, William W Riley, Guang Yang, Xiyang $\mathrm{Wu}$, Shuze Tang. Effects of Anisakis Allergenic Proteins on FishBorne Food Safety Risks. Mod Concep Dev Agrono. 8(4). MCDA. 000693. 2021. DOI: 10.31031/MCDA.2021.08.000693

Copyright@ Shuze Tang. This article is distributed under the terms of the Creative Commons Attribution 4.0 International License, which permits unrestricted use and redistribution provided that the original author and source are credited.

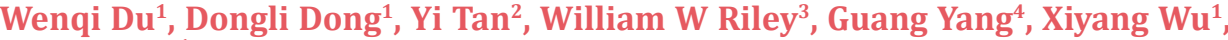 \\ Shuze Tang ${ }^{1 *}$ \\ ${ }^{1}$ Department of Food Science and Engineering, Jinan University, Guangzhou, China \\ ${ }^{2}$ Ningbo Customs, Beilun, Ningbo, China \\ ${ }^{3}$ International School, Jinan University, Guangzhou, China \\ ${ }^{4}$ School of Medicine, Jinan University, Guangzhou, China
}

\begin{abstract}
Anisakis (mainly Anisakis spp.) is a global public health and socio-economic concern. The infective third stage larva (L3) of these nematodes, which may be present in the muscle of fish and squid, is the etiological agent of an underestimated, emerging fish-borne zoonotic disease called anisakiasis (or anisakidosis). With the globalization of the seafood industry and the diversification of eating habits, anisakiasis is distributed worldwide, which seriously threatens human health. However, the risk of humans acquiring anisakiasis in developed countries with the habit of raw fish consumption appears to be underestimated.

Current knowledge of Anisakis as a food-borne parasite with special focus on Anisakis larvae infection in marine fish, life cycle, geographical distribution, epidemiology, allergenic protein residue of $A$. simplex, are critically reviewed. Research on residues from allergenic proteins of Anisakis remained in processed fish products and their health risks to susceptible consumers are discussed for prevention and control of this parasite.

Anisakis is ubiquitous in the world's oceans, but there are differences in the number and species of this nematode with geographical location. Conventional thermal processing like freezing, heating, smoke curing and non-thermal processing such as salting and pressure have shown potential effects on elimination or reduction of food allergenic proteins, however, similar effects on residual Anisakis allergenicity are unknown. Potential harm or risk of these parasitic allergenic proteins to consumers is scarce in the published literature. Further research on assessment and technical control of Anisakis allergenic proteins in fish-borne food is proposed for fish food safety in aquatic industry.
\end{abstract}

Keywords: Anisakis; Allergens; Anisakiasis; Prevalence of sensitization

Abbreviations: WHO: The World Health Organization; EFSA: The European Food Safety Authority; ES: Excretory-Secretory; IgE: Immunoglobulin E; FDA: The United States Food and Drug Administration; IUIS: International Union of Immunological Societies; GAA: gastro-allergic anisakiasis; ELISA: EnzymeLinked Immuno Sorbent Assay

\section{Introduction}

The World Health Organization (WHO) estimates that more than 56 million cases of parasite infections associated with the consumption of fish products occur annually. There is a group of Anisakids among the parasites implicated, and it is responsible for an important foodborne zoonotic parasitic disease that seriously threatens human health [1]. Anisakids (mainly Anisakis spp.) are of public health and socio-economic concern globally. From the current 9 recognized species, A. simplex sensu stricto (s.s.) and A. pegreffii are the most frequently reported and hygienically relevant, as they are responsible for anisakiasis [2].

Marine mammals, such as whales and dolphins, are the final hosts of Anisakis species, and the adults reside within the stomach of the hosts, laying eggs that are excreted in the feces [3]. Subsequently, second-stage larvae hatch and are eaten by small crustaceans (krill) 
before developing into third-stage larvae. These mature larvae are consumed by marine fish, eel and squid, and they then migrate into the viscera and peritoneal cavity. When these intermediate hosts are consumed by marine mammals, the larvae grow into adult worms, thus completing the lifecycle. Humans are incidental hosts, and the larvae cannot grow or replicate inside a human host (Figure 1).

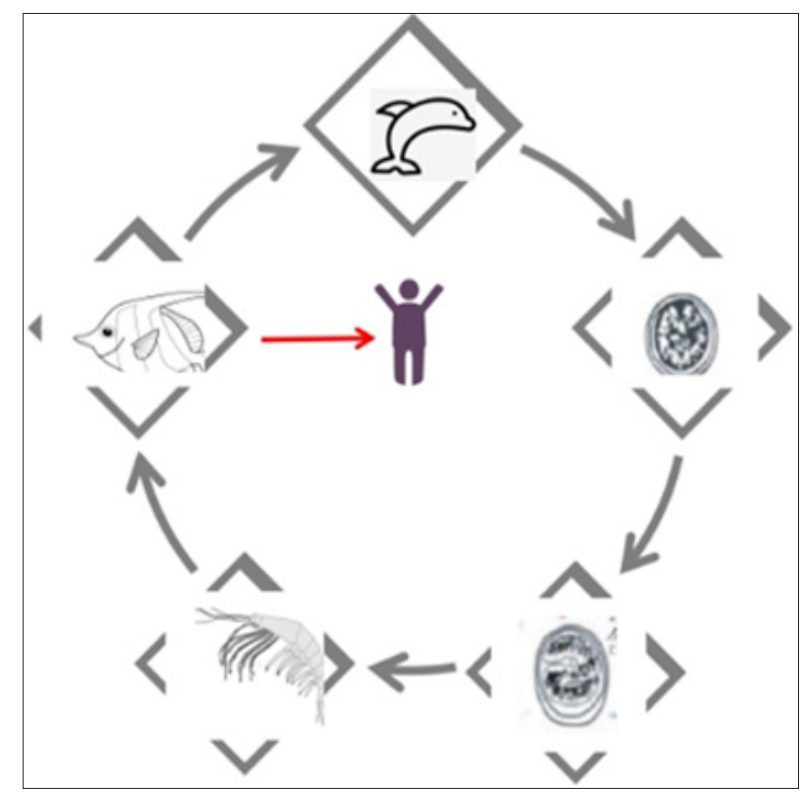

Figure 1: Life cycle of Anisakis simplex, including accidental human host.

Humans may be infected and develop disease after eating raw or under cooked parasitized fishery products, such as traditionally marinated anchovies in Spain (boquerones en vinagre) and Italy (alici marinate), Japanese sushi and sashimi (eaten worldwide) and South American ceviche.

\section{Geographical and host distributions}

Since 1960, when anisakiasis was first described, thousands of cases have been reported in Japan and hundreds in Europe, as well as in other parts of the world [4]. The European Food Safety Authority (EFSA) summarized that prior to 2010, approximately twenty thousand human cases have been reported worldwide, with most occurring in Japan and Spain [5]. However, this number is thought to be an underestimation, since in Spain alone, $\sim 8,000$ cases per year have been estimated [6]. The large majority of the world's cases are reported in Japan [5], where more than 20,000 people have been infected with this disease, and it is increasing at a rate of $>2,000$ cases per year [7], due primarily to Japan's traditional raw culinary eating habits in association with one of the highest seafood consumption levels in the world. Other countries with high incidences of anisakiasis include the Netherlands and Germany [8]. China reported its first case of anisakiasis in 2013 [9]. Between 2010 and 2014, $\sim 80$ human anisakiasis reactions (the human allergy caused by Anisakis sp. infestation) have been recorded by the French, with 4-14 cases each year [10]. In Poland, the first instance of this disease was described in 2020 [11].
Anisakis is widely distributed, with infections of the terminal host or the intermediate host having been reported in all the world's major waters, but mainly distributed along the North Pacific and North Atlantic coasts and their islands. At present, more than 30 countries or regions have identified $>200$ species of fish and 25 species of cephalopods that can be infected with Anisakis [12]. Distribution of Anisakid larvae species differs between locations [13]. The presence of the final host plays a significant role, as each Anisakid species has a preference for certain marine mammal hosts which are linked to different geographic regions [14]. A. simplex is more abundant in the Atlantic Ocean and A. pegreffii predominates in the Mediterranean Sea [15]. Pseudoterranova spp. have only been reported in low numbers in the North East Atlantic and South Pacific [16]. Hybrids of A. simplex and A. pegreffii have been found in the North West Atlantic along with A. simplex and A. pegreffii. Species of fish that occur in multiple oceans have different larvae distribution profiles between oceans. For example, European hake (Merluccius merluccius) and blue whiting (Micromesistius poutassou) are predominantly infected with A. simplex in the Atlantic Ocean, while in the Mediterranean Sea, $A$. pegreffii (and to some level $A$. physeteris) infections were found in these two species [14].

The fish with the highest infection rates are cod (Gadus morhua) - 88\%, herring (Clupea harengus) - 88\%, rockfish (Sebastes spp.) - 86\% [17]. While some fish species are more abundant in one specific ocean or sea, such as cod in the North Atlantic, or mackerel (Scomber scombrus) in the North Sea, most fish have a more widespread distribution, where differences in the prevalence of Anisakidae between the bodies of water are readily evident. For example, the prevalence of larvae in blue whiting and anchovy (Engraulis encrasicolus) are 23\% and 1\%, respectively, in the Mediterranean Sea compared to $92 \%$ and $78 \%$, respectively, in the North East Atlantic Ocean. This could be related to the presence and infective status of the terminal host, the presence of the intermediate hosts, and the interactions among all hosts, which differ in each body of water [18]. The general occurrence of Anisakidae is thereby considered higher in the Atlantic Ocean compared to the Mediterranean Sea due to the higher abundance of cetaceans (final hosts), among other factors [19-21].

In the waters near East Asia, Anisakis also exhibits regional differences. A. simplex sensu stricto is mainly distributed off the Pacific coast of north western Japan, and A. pegreffii is mainly found in the area from the Sea of Japan to the coast of China [22]. Quiazon et al. [23] conducted a comprehensive survey of various marine fish in six different locations near Japan and found that $A$. simplex sensu stricto and A. pegreffii predominate around the coastline of Japan, although there are a small number of other species of Anisakis [24]. Among them, A. simplex sensu stricto was found distributed in the North and on the Pacific coast, and A. pegreffii was discovered in the South on the coast of the Sea of Japan. In the waters near South Korea, the infection rate of $A$. pegreffii in sea eels is $86.8 \%$, while the infection rate of typical Anisakis is 7.8\%, and 5.4\% are unspecified, indicating that $A$. pegreffii has a selective advantage in the waters near South Korea (Table 1) [25-30]. 
Table 1: Investigation of Anisakis larvae infection in marine fish around the world.

\begin{tabular}{|c|c|c|c|c|c|}
\hline Origin & Year & Anisakis & Fish species & $\begin{array}{c}\text { Infection Rate } \\
(\%)\end{array}$ & Ref. \\
\hline $\begin{array}{c}\text { Ligurian Sea (Mediterranean } \\
\text { Sea) }\end{array}$ & 2013 & A. pegreffii & $\begin{array}{l}\text { Mullus barbatus } \\
\text { Serranus scriba } \\
\text { T. trachurus }\end{array}$ & 21.5 & $\begin{array}{c}\text { Serracca et al. } \\
{[26]}\end{array}$ \\
\hline $\begin{array}{c}\text { Alborán Sea (Mediterranean } \\
\text { Gibraltar area) }\end{array}$ & 2014 & $\begin{array}{c}\text { A. pegreffii } \\
\text { A. simplex sensu stricto }\end{array}$ & T. trachurus & 61.5 & Piras et al. [27] \\
\hline Iberian waters （Atlantic Ocean） & 2015 & $\begin{array}{c}\text { A. simplex sensu stricto } \\
\text { A. pegreffii }\end{array}$ & Sardina pilchardus & 10 & $\begin{array}{l}\text { Molina -Fernán- } \\
\text { dez et al. [28] }\end{array}$ \\
\hline $\begin{array}{l}\text { Papua New Guinea } \\
\text { (Western Pacific) }\end{array}$ & 2013 & $\begin{array}{c}\text { Anisakis Type I larvae } \\
\text { (A. typica) }\end{array}$ & $\begin{array}{c}\text { Selar crumenophthalmus } \\
\text { Gerres oblongus } \\
\text { Thunnus albacares }\end{array}$ & 7.6 & Koinari et al. [29] \\
\hline $\begin{array}{c}\text { Pacific stock (the Pacific coast of } \\
\text { Japan) }\end{array}$ & 2010 & $\begin{array}{c}\text { A. pegreffii } \\
\text { A. simplex sensu stricto }\end{array}$ & Scomber japonicus & 74.3 & Suzuki et al. [30] \\
\hline Republic of Korea & 2015 & $\begin{array}{l}\text { A. pegreffii } \\
\text { A. typica }\end{array}$ & Astrocongermyriaster & 100 & Cho et al. [25] \\
\hline
\end{tabular}

Note: Infection rate (\%)=Number of infected fish / total number of checked fish x 100 .

The infection rate of Anisakis in fish on the Pacific coast of China is also very high. Zheng [31] studied a variety of marine fish near Xiamen, Fujian Province, some of which had an infection rate as high as $100 \%$, including A. pegreffii and A. simplex. Li et al. [32] investigated 40 fish species (311 fish in total) in the Yellow Sea and found a total of 1709 A. pegreffii larvae, which accounted for $98.7 \%$ of the total number of Anisakis larvae enumerated, indicating that A. pegreffii is most abundant in the Yellow Sea. Li [33] investigated hairtail (Trichiurus lepturus), yellow croaker (Larimichthys polyactus), and mackerel in the East China Sea and found that the East China Sea is dominated by A. pegreffii. Shi et al. [34] investigated 35 species of marine fish (327 fish in total) in the South China Sea. Most of these fish were infected with $A$. typical, while a few were infected with A. pegreffii and A. physeteris, and others were unspecified. The infection situation is different from other sea areas around China.

Table 2: Investigation of Anisakis larvae infection in marine fish in China.

\begin{tabular}{|c|c|c|c|c|c|c|c|}
\hline Origin & Year & Fish Species & $\begin{array}{c}\text { Infection } \\
\text { Species }\end{array}$ & Check Sum & $\begin{array}{c}\text { Infection Rate } \\
\text { (\%) }\end{array}$ & High Intensity Infection \\
\hline Zhoushan (Import) & 2015 & 19 & 14 & 660 & 56.97 & Gadus (New Zealand) & Li et al. [32] \\
\hline Zhoushan (Export) & 2015 & 19 & 14 & 378 & 57.94 & $\begin{array}{c}\text { Pneumatophorus japoni- } \\
\text { cus, Lophius litulon, Gadus, } \\
\text { Nemipterus virgatus }\end{array} \quad$ Li et al. [32] \\
\hline $\begin{array}{c}\text { Guangzhou (Im- } \\
\text { port) }\end{array}$ & $2012-$ & 9 & 9 & 63 & 93.7 & Ephippus orbis \\
\hline $\begin{array}{c}\text { Yantai (Domestic } \\
\text { market) }\end{array}$ & 2015 & 2017 & 20 & 6 & 708 & 15.82 & $\begin{array}{c}\text { Larimichthys polyactis } \\
\text { Trichiurus lepturus }\end{array}$ \\
\hline
\end{tabular}

In addition, at China's Zhoushan, Taizhou and Guangzhou import and export ports, different types of marine fish have been found to have Anisakis infections, mainly A. simplex (s.s.) and A. pegreffii, both of which are the most important pathogens that cause human anisakiasis, indicating that there is a risk to consumers of contracting Anisakis disease from imported marine fish [35-37]. In the domestic market, there is still a potential risk of Anisakis infection from fresh sea fish (Table 2). Data show that hairtail, mackerel and small yellow croaker have the highest infection rates [38-41]. Disease of Anisakis is a second type of parasitic disease that is prohibited from entering China. Statistics show that the main detection parts of Anisakis are distributed in the body cavity, stomach, intestine, liver and pancreas, and gonads of marine fish, while there are few or even no parasites in the muscle tissue. 


\begin{tabular}{|c|c|c|c|c|c|c|c|}
\hline $\begin{array}{l}\text { Dongtai (Domestic } \\
\text { market) }\end{array}$ & 2018 & 5 & 4 & 149 & 52.35 & $\begin{array}{c}\text { Trichiurus lepturus } \\
\text { Scomberomorus niphonius } \\
\text { Pneumatophorus japonicus } \\
\text { Larimichthys polyactis }\end{array}$ & Zhang et al. [41] \\
\hline $\begin{array}{c}\text { Fujian Province } \\
\text { (Domestic market) }\end{array}$ & $\begin{array}{l}2016- \\
2018\end{array}$ & 32 & 19 & 810 & 34.2 & $\begin{array}{c}\text { Trichiurus lepturus } \\
\text { Scomberomorus niphonius }\end{array}$ & Lin et al. [39] \\
\hline $\begin{array}{l}\text { Jiangsu Province } \\
\text { (Domestic market) }\end{array}$ & 2018 & Unknown & Unknown & 494 & 64 & $\begin{array}{c}\text { Trichiurus haumela } \\
\text { Pneumatophorus japonicas }\end{array}$ & Mao et al. [40] \\
\hline
\end{tabular}

Note: Infection rate $(\%)=$ Number of infected fish (not shown) / sum of checked fishx100.

\section{Routes of exposure and epidemiology}

Adult Anisakis is parasitic in the digestive tract of marine mammals, while the larvae are widely parasitized in different species of marine fish [44]. The infestation in humans results from accidental ingestion of the larvae. If a person eats raw or inadequately cooked marine fish containing Anisakis larvae, such as sushi, sashimi, etc, it can cause anisakiasis symptomized clinically as four main clinical types: gastric, intestinal, extragastrointestinal and allergic. Within 8-12 hours, the Anisakis larvae bore into the digestive tract or migrate to other tissues, causing acute abdominal pain, indigestion, nausea, vomiting and diarrhoea due to pathologic index of edema, hyperaemia, and bleeding in the surrounding mucosa [45-47]. This acute gastrointestinal form of Anisakis infection is usually transient, with the worm dying within a few weeks. Diagnosis is generally obtained through anamnestic data, endoscopy, radiography, serum specific anti-Anisakis IgE determination, or surgery if the worm has become embedded.

The presence of the parasite in the extra-gastrointestinal omental fat is unexpected and unusual. The invasive capacity of Anisakis is nonetheless known, and cases of larvae penetrating the abdominal cavity through the abdominal wall, and its association within inguinal hernias, have been described [49]. Hajjar et al. [42] presented the case of a female Canadian patient with an Anisakis larvae in an incarcerated ventral hernia, while Kawashima [43] reported a case of gastrointestinal hemorrhage due to ulcer formation caused by the invasion of the bowel wall by an Anisakis larva.

In addition to gastrointestinal symptoms, anisakiasis may sometimes cause allergic symptoms, such as urticaria, angioedema and even anaphylaxis [50-53]. Kasuya et al. [48] reported that sensitization to A. simplex, but not to a fish allergy, was the cause of some urticaria episodes present in Japanese patients who consumed cooked mackerel. The larvae penetrate the gastrointestinal mucosa-leading to an inflammatory response with a generalised immunoglobulin E (IgE)-mediated allergic reaction, resulting in an ulcer, an eosinophilic granuloma, or even gastrointestinal perforation [54]. Following the description in Spain of a case of recurrent anaphylaxis caused by $A$. simplex parasitizing fish, it became clear that both skin tests and specific IgE determination were useful tools in the diagnosis of this type of sensitization [55].
A. simplex is, so far, the only described parasite associated with fishery products that can cause allergic responses [5], gastroallergic reactions by $A$. pegreffii have been reported in Italy [56].

\section{Allergenic sources}

Patients may be exposed primarily to somatic antigens from dead larvae in food, excretory-secretory (ES) antigens when there is expulsion or surgical removal of the intact larvae, or both [57]. In the case of anisakiasis, excretory/secretory products contain proteins with higher allergenic potential than somatic components [60].

In human anisakidosis, the patient may be exposed to A. simplex antigens from any of three sources:

i. Proteases and protease inhibitors secreted when the larvae invade, that is, excreted and secreted allergens, which lead to exposure to the complete profile of the parasite's antigens.

ii. Allergens from the worm itself, which are cuticular and somatic antigens from dead larvae contained in food.

iii. Epidermal allergens which are used to protect the digestive juice of the host.

To date, there are 19 allergens that have been identified and described in Anisakis [61]. However, a recent proteomic study combining 2D gel analysis and western blotting described 28 immunoreactive proteins present in the species complex $(A$. simplex, A. pegreffii, and their hybrids), including intraspecies variations which could be assessed as potential allergens. The result also showed that $A$. simplex (s.s.) (34 different protein spots) was more allergenic than $A$. pegreffii (11 different protein spots) and that both species were more allergenic than their hybrids ( 6 protein spots) [62].

\section{Allergens of Anisakis simplex}

To date, 14 allergens of $A$. simplex (s.s.) have been confirmed and described in detail, many of which have been well characterised by molecular methods [63] (Table 3). Officially designated Ani s 1 to Ani s 14, allergenic activity, according to the criteria of the WHO/IUIS Committee, has been verified in these allergens. Eight allergens, Ani s 1, Ani s 4, Ani s 5, Ani s 6, Ani s 7, Ani s 8, Ani s 9 and 
Ani s 13 are parasite excretion/secretion molecules, while Ani s 2, Ani s 7 are the main allergens, and Ani s 4, Ani s 5, Ani s 6, Ani s 8, Ani s 3 and Ani s 10 are somatic antigens. Ani s 1, Ani s 2, Ani s 3 and Ani s 9 and Ani s 10 are minor allergens.

Table 3: Anisakis simplex allergens approved by the WHO/IUIS Allergen Nomenclature Sub-Committee.

\begin{tabular}{|c|c|c|c|c|}
\hline Allergen & $\begin{array}{c}\text { Molecular Weight } \\
\text { (kDa) }\end{array}$ & Nematode Antigen & Protein & Reactivity in Infected Patients (\%) \\
\hline Ani s 1 & 24 & ES & Kunitz-type trypsin inhibitor & 85 \\
\hline Ani s 2 & 100 & Somatic & Paramyosin & 88 \\
\hline Ani s 3 & 41 & Somatic & Tropomyosin & 27 \\
\hline Ani s 4 & 9 & ES & SXstatin & 25 \\
\hline Ani s 5 & 15 & ES & Serine protease inhibitor & 13 \\
\hline Ani s 6 & 7 & ES & Sa3 recognized allergen & 94 \\
\hline Ani s 7 & 139 & ES & SXP/RAL protein & 25 \\
\hline Ani s 8 & 16 & ES & Not given & 14 \\
\hline Ani s 9 & 15 & Somatic & Not given & 39 \\
\hline Ani s 10 & 23 & Unknown & Not given & 50 \\
\hline Ani s 11 & 30 & Unknown & Haemoglobin & 57 \\
\hline Ani s 12 & 33 & ES & Not given & 54 \\
\hline Ani s 13 & 37 & Unknown & \\
\hline Ani s 14 & 23.5 & & 54 \\
\hline
\end{tabular}

Note: ES, excretory/secretory. Reactivity, percentages of infected patients positive to individual allergenic protein.

Ani s 1 is considered the main allergen of this species and is known to occur in different isoforms [64]. Moneo et al. [58] purified crude parasite extracts by ethanol precipitation and reversedphase high-performance liquid chromatography to obtain a protein with a molecular weight of $24 \mathrm{kDa}$ (belonging to the nematode troponin family). At the same time, Arrieta et al. [59] also found a $21 \mathrm{kDa}$ protein by constructing the cDNA library, Western blot hybridization analysis and conducting other experiments. The $24 \mathrm{kDa}$ allergens discovered by Moneo et al. [58] and the $21 \mathrm{kDa}$ allergens discovered by Arrieta et al. [59] were all named Ani s 1. More than $50 \%$ of anisakiasis patients have antibodies to Ani s 1, indicating that it is a major allergen. Most gastro-allergic anisakiasis patients have anti-Ani s 1 specific immunoglobulin (Ig) E (67-85\%), but Ani s 1 antibodies are not found in the serum of asymptomatic individuals. Ani s 1 is heat stable and can act as a food allergen, causing clinical reactions upon secondary exposure, immediately following the ingestion of cooked fish [58].

Ani s 2 and Ani s 3 are the two somatic allergens described so far. They are paramyosins and tropomyosin proteins, respectively, and they are similar to the paramyosins and tropomyosin's of other species [67]. The molecular weight of Ani s 2 is $100 \mathrm{kDa}$. Because of its high sequence homology with flukes and arthropods, it can cause a cross-immune reaction [70]. Asturias [71-72] discovered the allergen Ani s 3, which is considered to be a less important protein allergen in A. elegans. The molecular weight of this protein is $41 \mathrm{kDa}$. Interestingly, nematode tropomyosin's may also represent vaccine candidates, as they have been shown to elicit antibodymediated protective immunity against different larval stages of the Trichostrongylus colubriformis (Trichostrongyloid nematode) and the Onchocerca volvulus (Filarioid nematode) [73]. In a similar manner, Sereda et al. [65] found that serum antibodies against haemoglobin of $A$. pegreffii induced an immunogenic response in mice against infection by Nippostrongylus brasiliensis (hookworm).

Moneo et al. [66] extracted an allergen from the E/S protein of Anisakis. Ani s 4 is located both in the excretory gland and below the cuticle, and it is heat stable (boiling for $30 \mathrm{~min}$ ) and resistant to pepsin digestion [75]. Protein glycosylation is not a part of the allergic reaction. The molecular weight of the Ani s 4 allergen is $9 \mathrm{kDa}$. In that study, it was found that after heating the extract of the parasite, some patients still had a reaction, with Anis 4 being recognized by $27 \%$ of allergic patients. Margarita et al. [68] used various technological and food processing treatments on parasitized fish to kill the Anisakis larvae and prevent infection and consumer sensitization. However, dot blot analysis indicated a high loss of Ani s 4 recognition post-canning, but residual antigenicity was still present. In addition, patients who can recognize this allergen are observed to have more frequent allergic attacks than those who are not sensitive to it.

Kobayashi et al. [69] used the serum of patients with anisakiasis to construct a cDNA expression library and do immune-screening, and they obtained two positive clones that encoded allergens (namely, Anis 5 and Anis 6). The molecular weight of Anis 5 is $15 \mathrm{kDa}$, and it is a thermostable ES allergen. Ani s 6 (7kDa), is homologous to serine protease inhibitors from Boophilus microplus (cattle tick), Anopheles stephensi (mosquito) and Glossina morsitans (tsetse fly), including the Apis mellifera (honeybee) allergen Api m 6 [63]. Neither of them is major allergens of A. simplex [77]. However, in one study, Ani s 5 was recognised by serum antibodies in $49 \%$ of patients $(41 / 84)$. 
Ani s 7 is also a major allergen of Anisakis, which is an ES product of approximately $139 \mathrm{kDa}$ [79]. The native form is glycosylated and recognized by IgE from $100 \%$ of infected subjects, which gives it a great diagnostic value [80]. However, there is no experimental support for the allergenicity of this molecule [50].

Ani s $8(15 \mathrm{kDa})$ and Ani s $9(14 \mathrm{kDa})$, which share protein sequence homology, are recognized by $25 \%$ and $13 \%$ of $\operatorname{IgE}$ from subjects sensitized to Anisakis, respectively. Both belong to the SPX/RAL-2 family [81], which also includes Ani s 5, and they are heat-stable and present in excretory/secretory products. Five of thirty-six Anisakis allergic patients (13.8\%) were positive for Ani s 9 [81]. Cho used an experimental mouse model to evaluate the allergenicity of Ani s 9 allergens from A. simplex (whale worm) third stage larvae. The result showed that repeated treatment with the allergen could elicit airway inflammation, including eosinophilia and high Ovalbumin-specific IgE levels [83]. Although Ani s 9 is reportedly more abundant in crude somatic extracts from Anisakis, its biological function is unknown.

Anisakis haemoglobin has been described as a major allergen (Ani s 13), and there is an absence of IgE cross-reaction to Ascaris haemoglobin in Anisakis patients. In addition, Ani s 13 has shown high rates of recognition (80.9\% of the GAA patients) using a specific antigen-capture ELISA [84]. However, further confirmatory studies are needed.

Kobayashi et al. [76] identified Ani s 14 as a new major allergen of $A$. simplex by means of the chemiluminescent immune-screening method. As a result, an IgE-positive clone coding for a $23.5 \mathrm{kDa}$ protein composed of 217 amino acid residues was isolated. Recombinant Ani s 14 was verified to be IgE reactive, and hence could be useful as a diagnostic tool for A. simplex allergy. Although the amino acid sequence of Ani s 14 is partly homologous to those of Ani s 7 and 12, it is structurally unique and does not belong to any known protein families [55].

So far, as many as 14 types of proteins (Ani s 1-14) have been identified as A. simplex allergens, but more unknown allergens may exist. Future studies with this immune-screening method using sera from other patients would further identify more unknown $A$. simplex allergens.

\section{Allergenic protein residue}

Control measures against Anisakidae focus on the prevention of their post-mortem migration from the viscera to the muscles and on the removal or inactivation of the larvae present in captured fish. The United States Food and Drug Administration (FDA) has listed guidelines for seafood freezing below $-35^{\circ} \mathrm{C}$ for more than 15 hours or freezing below $-20^{\circ} \mathrm{C}$ for more than 7 days. Additionally, food business operators must conduct a visual inspection of all fishery products, and they must remove all visible parasites during industrial processing. However, the A. simplex (s. s.) L3 larvae may be freeze tolerant despite the rapid cooling of nematodes to $-20{ }^{\circ} \mathrm{C}$, according to the sanitary authorities of the USA and the EU [85].
Podolska et al. [78] used malachite green staining reaction to identify the viability of frozen A. simplex (s.s.) larvae. Results showed that $84 \%$ A. simplex (s.s.) larvae was dead but $16 \%$ uncertain due to motionless but also colourless [78,87]. This phenomenon indicated that freezing may not completely kill the A. simplex (s.s.) larvae and the allergenic proteins may remain unchanged [89].

Freezing conditions may have a profound effect on the subsequent safety of fish products. Łopieńska-Biernat et al. [82] found that a rapid freezing rate is optimal to ensure the safety of fish products relative to Anisakis larvae mortality. However, although high freezing rates may be preferable for the rapid killing of Anisakis larvae and in maintaining optimum eating quality, they may cause a greater release of antigens to the surrounding medium [86].

Heating to $\geq 60{ }^{\circ} \mathrm{C}$ at the core of the product for at least 1 min also ensures the destruction of the larvae [90,91]. However, Sánchez-Alonso et al. [92] found that conditions reported in the EU Regulation should be revisited, since reaching $60{ }^{\circ} \mathrm{C}$ for $1 \mathrm{~min}$ in the thermal centre would not be sufficient to kill all L3, and at least $8 \mathrm{~min}$ of heating are needed. Simultaneously, immunoblot studies using sera from Anisakis-sensitized patients have shown that some allergenic proteins of Anisakis are not inactivated after thermal treatments [75]. Some authors claim that exposure to nonviable Anisakis material can result in allergic symptoms in previously sensitized patients, indicating that parasite allergens are resistant to the thermal treatments of the usual cooking procedures $[50,60,93]$. Anisakis larvae can also be a source of allergens in what is considered secured food in the canning industry (following processing with technological treatments). This appears related to the existence of thermostable and pepsin resistant parasite allergens. Tejada et al. [88] analyzed allergen stability during heating to $121^{\circ} \mathrm{C}$ in an autoclave to simulate the thermal processing applied to canned fish. Some relevant $A$. simplex allergens retained their capacity to bind immunoglobulin $\mathrm{E}$ and activate basophils post-autoclaving. It can be assumed that the salting and heating process during canning kills the nematode larvae and eliminates the zoonotic potential for anisakiasis. However, an allergenic potential remains through the presence of Ani s 1 and Ani s 4 in the canned products [94]. Therefore, heat-stable allergens are important (such as Ani s 4), even if classified as "minor allergens" (due to the frequency of recognition by patient sera), because these allergens relate to allergic reactions to cooked or canned (anisakid infected) fish [90].

Some researchers have used IgG hybrid analysis to analyse the simple Anisakis allergens and found that Ani s 4 can be quantified in frozen, fresh, and heated fish at different temperatures, which can be used as a signal for the presence of Anisakis in fish [95]. Leticia showed a different intensity and frequency of response to AnisakisIgE measured by Immuno CAP and Ani s 1 by ELISA, between $A$. simplex allergic patients and asymptomatic sensitized populations. Also, higher frequency of recognition of the r Ani s 1 allergen was 
found in patients who have experienced a severe reaction compared to those who had suffered a mild to moderate reaction [96].

Thus, the very high prevalence of Anisakis in the imported frozen mackerel still poses a significant risk for consumers because Anisakis allergens are heat-stable or resistant to pepsin and deepfreezing methods even in processed food. Two cases of immediate allergies to Anisakis after ingestion of processed seafood have been reported. In case 1, a 75-year-old man was diagnosed with IgEmediated allergy due to A. simplex after the ingestion of salted fish guts made of Sagittated calamari, indicating that Ani s 3 was the causative allergen in this case [97]. In case 2, a 62-year-old man ingested dressed salmon and its roe (ikura) and grilled mackerel, ELISA with 11 natural or recombinant A. simplex allergens (Ani s 1-6, 8, 9, 11 and 12 and troponin C-like protein) showed that the patient serum strongly reacted to Ani s 1 and Ani s 12 and weakly to Ani s 2 and troponin C-like protein [98].

To date, freezing and heating are the most effective processes available to inactivate anisakid larvae. Many traditional cooking methods that have been used to kill anisakid larvae, such as salting [99], smoke curing, high hydrostatic pressure [100] and marinating [101] have proven to be ineffective if the treatment period is too short or they lower the product quality during the killing process. Air-dried stockfish do not carry viable anisakid nematodes, but the potential presence of allergenic proteins in the product may still pose a health risk for sensitized consumers and, thus, this source warrants further investigation [102].

\section{Conclusion and Future Prospects}

With the promulgation of new international standards on food safety, risk assessment methods are now based on scientific principles and directed at solving global public health problems, and the safety standards and monitoring standards as well as methods of canning fish are continuously improving. To date, the detection of Anisakids in fresh and processed fish products has been successful using real-time polymerase chain reaction (PCR [103], ultraviolet fluorescent imaging [104], IgG antibody immunoblotting [105] and enzyme-linked immunosorbent assay (ELISA) [106]. Different countries have different regulations and/or non-mandatory guidelines for the control of nematodes, including A. simplex, in fish and fish products, particularly for importation. In some countries, such as South American nations, the judgment that "canned fish is dangerous for consumers' health due to the presence of parasites" appears, but the parasites associated with marine fish are inevitable [107]. Therefore, whether the activity of allergenic proteins still exists after being processed by high-temperature and/ or high-pressure processes such as canning, bringing with it food safety risks, is a very important question. A recent study identified an increased importance of Anisakis during the last few decades, with potential adverse effects on fish and human health, and on the world's fisheries [108].

\section{Acknowledgement}

The authors are grateful to the National Key Research and Development Project (2018YFG1602500) for its support. This research was also supported by the Joint Innovation Project of the Hong Kong-Guangdong Province (2016A05053031).

\section{References}

1. Pampiglione S, Rivasi F, Criscuolo $M$, Benedittis $A D$, Gentile A, et al. (2002) Human anisakiasis in Italy: A report of eleven new cases. Pathol Res Pract 198(6): 429-434.

2. Mattiucci S, Cipriani P, Levsen A, Paoletti M, Nascetti G (2018) Molecular epidemiology of anisakis and anisakiasis: An ecological and evolutionary road map. Adv Parasitol 99: 93-263.

3. Sasaki T, Fukumori D, Matsumoto H, Ohmori H, Yamamoto F (2003) Small bowel obstruction caused by Anisakiasis of the small intestine: Report of a case. Surg Today 33(2): 123-125.

4. Audicana MT, Ansotegui IJ, de Corres LF, Kennedy MW (2002) Anisakis simplex: dangerous — dead and alive? Trends Parasitol 18(1): 20-25.

5. EFSA Panel on Biological Hazards (BIOHAZ) (2010) Scientific opinion on risk assessment of parasites in fishery products. EFSA Journal 8(4): 1543.

6. Bao M, Pierce GJ, Pascual S, González Muñoz M, Mattiucci S (2017) Assessing the risk of an emerging zoonosis of worldwide concern: anisakiasis. Sci Rep 7: 43699.

7. Arizono N, Yamada M, Tegoshi T, Yoshikawa M (2012) Anisakis simplex sensu stricto and Anisakis pegreffii: biological characteristics and pathogenetic potential in human anisakiasis. Foodborne Pathog Dis 9(6): 517-521.

8. Cheng ZY, Shi YN, Zhang SY (2019) Anisakiasis of food-borne parasitic disease. The Guide of Sci Educ (8).

9. Qin YH, Zhao YF, Ren YX, Zheng LL, Dai XD, et al. (2013) Anisakiasis in China: the first clinical case report. Foodborne Pathog Dis 10(5): 472474 .

10. Molina Fernández D, Malagón D, Gómez Mateos M, Benítez R, Martín Sánchez J et al. (2015) Fishing area and fish size as risk factors of Anisakis infection in sardines (Sardina pilchardus) from Iberian waters, southwestern Europe. Int J Food Microbiol 203: 27-34.

11. Kołodziejczyk L, Szostakowska B, Sobecka E, Szczucki K, Stankiewicz K (2020) First case of human anisakiasis in Poland. Parasitol Int 76: 102073.

12. Wu GL (2013) Human parasitology. Chinese J Parasitol Parasitic Dis 31(3): 228.

13. Kuhn T, García-Màrquez J, Klimpel S (2011) Adaptive radiation within marine anisakid nematodes: a zoogeographical modeling of cosmopolitan, zoonotic parasites. PloS one 6(12): e28642.

14. Mercken E, Damme IV, Serradell A, Gabriël S (2020) Presence of Anisakidae in commercial fish species imported into the Belgian food markets: A systematic review and meta-analyses. Int J Food Microbiol 318: 10856.

15. Colombo F, Cattaneo P, Castelletti M, Bernardi C (2016) Prevalence and mean intensity of Anisakidae parasite in seafood caught in the Mediterranean Sea focusing on fish species at risk of being rawconsumed. A meta analysis and systematic review. Crit Rev Food Sci Nutr 56(9): 1405-1416.

16. Levsen A, Cipriani P, Mattiucci S, Gay M, Hastie LC, et al. (2018) Anisakis species composition and infection characteristics in Atlantic mackerel, Scomber scombrus, from major European fishing grounds-reflecting changing fish host distribution and migration pattern. Fish Res 202: 112-121.

17. Cao Z, liu JS, He F, Lin RQ, Zhu XQ (2004) Overview of Anisakiasis. J Trop Med (4): 494-497.

18. Valero A, López Cuello MM, Benítez R, Adroher FJ (2006) Anisakis spp. in European hake, Merluccius merluccius (L.) from the Atlantic off north- 
west Africa and the Mediterranean off southern Spain. Acta Parasitol 51(3): 209-212.

19. Rello FJ, Adroher FJ, Benítez R, Valero A (2009) The fishing area as a possible indicator of the infection by anisakids in anchovies (Engraulis encrasicolus) from southwestern Europe. Int J Food Microbiol 129(3): 277-281.

20. Rello FJ, Adroher FJ, Valero A (2008) Hysterothylacium aduncum, the only anisakid parasite of sardines (Sardina pilchardus) from the southern and eastern coasts of Spain. Parasitol Res 104(1): 117-121.

21. Valero A, Martín Sánchez J, Reyes Muelas E, Adroher FJ (2000) Larval anisakids parasitizing the blue whiting, Micromesistius poutassou, from Motril Bay in the Mediterranean region of southern Spain. J Helminthol 74(4): 361-364.

22. Blažeković K, Pleić IL, Đuras M, Gomerčić T, Mladineo I (2015) Three Anisakis spp. isolated from toothed whales stranded along the eastern Adriatic Sea coast. Int J Parasitol 45(1): 17-31.

23. Quiazon KM, Yoshinaga T, Ogawa K (2011) Distribution of Anisakis species larvae from fishes of the Japanese waters. Parasitol Int 60(2): 223-226.

24. Kong QM, Fan LF, Zhang JH, Akao N, Dong K, et al. (2015) Molecular identification of Anisakis and Hysterothylacium larvae in marine fishes from the East China Sea and the Pacific coast of central Japan. Int J Food Microbiol 199: 1-7.

25. Cho J, Lim H, Jung BK, Shin EH, Chai JY (2015) Anisakis pegreffii larvae in sea eels (Astroconger myriaster) from the South sea, Republic of Korea. Korean J Parasitol 53(3): 349-353.

26. Serracca L, Cencetti E, Battistini R, Rossini I, Prearo M, et al. (2013) Survey on the presence of Anisakis and Hysterothylacium larvae in fishes and squids caught in Ligurian Sea. Vet Parasitol 196(3-4): 547-551.

27. Piras MC, Tedde T, Garippa G, Virgilio S, Sanna D, et al. (2014) Molecular and epidemiological data on Anisakis spp. (Nematoda: Anisakidae) in commercial fish caught off northern Sardinia (western Mediterranean Sea). Vet Parasitol 203(1-2): 237-240.

28. Molina Fernández D, Rubio Calvo D, Adroher FJ, Benítez R (2018) Molecular epidemiology of Anisakis spp. in blue whiting Micromesistius poutassou in eastern waters of Spain, western Mediterranean Sea. Int J Food Microbiol 282: 49-56.

29. Koinari M, Karl S, Elliot A, Ryan U, Lymbery AJ (2013) Identification of Anisakis species (Nematoda: Anisakidae) in marine fish hosts from Papua New Guinea. Vet Parasitol 193(1-3): 126-133.

30. Suzuki J, Murata R, Hosaka M, Araki J (2010) Risk factors for Human Anisakis infection and association between the geographic origins of Scomber japonicus and Anisakid nematodes. Int J Food Microbiol 137(1): 88-93.

31. Zheng YM (2010) Studies on the identification method of Anisakis Nematodes in marine fish (Master degree thesis). Fujian Agriculture and Forestry University Press, Fuzhou, China.

32. Li J, Guo JN, Zhou JB, Shi W, Li WW, et al. (2013) Preliminary investigation of Anisakis sp. ${ }^{\text {rd }}$ stage larvae infection of Pneumatophorus japonicus from the Yellow Sea area. China J Food Saf 25(01): 56-61.

33. Li XJ (2009) A preliminary study on the infection status of Anisakis larvae in marine fish caught in the East China sea. Chin J Prev Vet Med 45(10): 76-77.

34. Shi MQ, Ming Z, An RP, Zhang LP (2013) Molecular identification and genetic diversity of Anisakis larvae (Nematode, Ascaridoidea) from marine fishes in the Bohai sea, China. Syst Zool 38(4): 687-694.

35. Huang YQ, Zhang S, He SH, Yao JW, Dai J, et al. (2017) Identification on the infection of Anisakis from marine fishes imported by Baiyun airport. Agr Sci China 44(04): 146-151.
36. Li YT, Yu WJ, Lu CC, Huang HY, Zhu SH, et al. (2014) A survey on infection of Anisakis in export seafood from Taizhou. Tianjin Agr Sci 20(05): 74 76.

37. Li XJ, Shen YY, Bai J (2016) Investigation of Anisakis larvae infection in import and export marine fish from Zhoushan. Anim Husb Vet Med 48(05): 119-122.

38. Gong CB, Wang ZX, Dong FG, Xing YF, Sun YL (2018) Investigation on infection of Anisakis sp. $3^{\text {rd }}$ stage larvae in fresh marine fish for sale in Yantai from 2016 to 2017. Modern Prev Med 45(10): 1766-1768.

39. Lin CX, Huang SL, Lin SH, Jiang DW, Xie HG (2019) Infection and species identification of Anisakis larvae in sea fishes along Fujian coast. Chin J Parasitol Parasitic Dis 37(04): 417-421.

40. Mao FZ, Sun BC, Ni BX, Zhang XY, Wu XM, et al. (2020) Investigation on the risk of Anisakis infection among high - risk populations along the coastal areas of Jiangsu Province. Chin J Schistosomiasis Control 32(3): 282-289.

41. Zhang XY, Yu M, Zhao QQ, Wang Y, Sun BC (2020) Investigation of Anisakis infections in market available marine fish in Dongtai city. Chin J Schistosomiasis Control 36(4): 426-427.

42. Hajjar R, Chakravarti A, Malaekah H, Schwenter F, Lemieux C, et al. (2020) Anisakiasis in a Canadian patient with incarcerated epigastric hernia. IDCases 20: e00715.

43. Kazumasa K, Fujiwara T, Katakura K, Gunji N, Yokokawa A, et al. (2019) Anisakiasis in the small intestine with excessive bleeding that was difficult to diagnose endoscopically. Intern Med J 58(1): 63-66.

44. Iñiguez AM, Santos CP, Vicente ACP (2009) Genetic characterization of Anisakis typica and Anisakis physeteris from marine mammals and fish from the Atlantic Ocean off Brazil. Vet Parasitol 165(3-4): 350-356.

45. Furukawa K, Yoshida K, Nojiri T, Ogawa M, Kohno S, et al. (2014) Adult intussusception caused by Meckel's diverticulum complicated by anisakiasis of the small intestine: report of a case. Clin J Gastroenterol $7(4)$ : 316-319.

46. Lim H, Jung BK, Cho J, Yooyen T, Shin EH, Chai JY, et al. (2015) Molecular diagnosis of cause of anisakiasis in humans, South Korea. Emerg Infect Dis 21(2): $342-344$.

47. Sohn WM, Chai JY (2011) Anisakiosis (anisakidosis) In Oxford textbook of zoonoses: biology. clinical practice, public health control $\left(2^{\text {nd }}\right.$ edn). Oxford University Press, Oxford, London, UK, pp: 774-786.

48. Kasuya S, Hamano H, Izumi S (1990) Mackerel-induced urticaria and Anisakis. Lancet 335(8690): 665.

49. Mitsuboshi A, Yamaguchi H, Ito Y, Mizuno T, Tokoro M, et al. (2017) Extra-gastrointestinal anisakidosis caused by Pseudoterranova azarasi manifesting as strangulated inguinal hernia. Parasitol Int 66(6): 810812.

50. Audicana MT, Kennedy MW. (2008) Anisakis simplex: from obscure infectious worm to inducer of immune hypersensitivity. Clin Microbiol Rev 21(2): 360-379.

51. Shweiki E, Rittenhouse DW, Ochoa JE, Punja VP, Zubair MH, et al. (2014) Acute small-bowel obstruction from intestinal Anisakiasis after the ingestion of raw clams; documenting a new method of marine-to-human parasitic transmission. Open Forum Infect Dis 1(2): ofu087.

52. Kang WH, Kim KS, Lee SH, Park YW (2019) Gastric anisakiasis after eating raw salmon. Dig Liver Dis 51(4): 602.

53. Shimamura Y, Muwanwella N, Chandran S, Kandel G, Marcon N (2016) Common symptoms from an uncommon infection: gastrointestinal Anisakiasis. Can J Gastroenterol Hepatol 2016: 5176502.

54. Kondo T (2018) Woe sushi: gastric anisakiasis. Lancet 392(10155): 1340 . 
55. Audicana MT, de Corres LF, Muñoz D, Fernández E, Navarro JA, et al. (1995) Recurrent anaphylaxis caused by Anisakis simplex parasitizing fish. J Allergy Clin Immunol 96(4): 558-560.

56. Mattiucci S, Fazii P, De Rosa A, Paoletti M, Megna AS, et al. (2013) Anisakiasis and gastroallergic reactions associated with Anisakis pegreffii infection, Italy. Emerging Infect Dis 19(3): 496-499.

57. Ivanovic J, Baltic MZ, Boskovic M, Kilibarda N, Dokmanovic M, et al. (2015) Anisakis infection and allergy in Humans. Procedia Food Sci 5: 101-104.

58. Moneo I, Caballero ML, Gómez F, Ortega E, Alonso MJ (2000) Isolation and characterization of a major allergen from the fish parasite Anisakis simplex. J Allergy Clin Immunol 106(1 Pt 1): 177-182.

59. Arrieta I, Barrio Md, Vidarte L, Pozo Vd, Pastor C, et al. (2000) Molecular cloning and characterization of an IgE-reactive protein from Anisakis simplex: Ani s 1. Mol Biochem Parasitol 107(2): 263-268.

60. Moneo I, Carballeda Sangiao N, González Muñoz M (2017) New perspectives on the diagnosis of allergy to Anisakis spp. Curr Allergy Asthma Rep 17(5): 27.

61. Fitzsimmons CM, Falcone FH, Dunne DW (2014) Helminth allergens, parasite-specific IgE, and Its protective role in Human immunity. Front Immunol 5: 61 .

62. Arcos SC, Ciordia S, Roberston L, Zapico I, Jiménez Ruiz Y, et al. (2014) Proteomic profiling and characterization of differential allergens in the nematodes Anisakis simplex sensu stricto and A. pegreffii. Proteomics 14(12): 1547-1568.

63. Baird FJ, Gasser RB, Jabbar A, Lopata AL (2014) Foodborne anisakiasis and allergy. Mol Cell Probes 28(4): 167-174.

64. Shimakura K, Miura H, Ikeda K, Ishizaki S, Nagashima Y, et al. (2004) Purification and molecular cloning of a major allergen from Anisakis simplex. Mol Biochem Parasitol 135(1): 69-75.

65. Sereda MJ, Hartmann S, Lucius R (2008) Helminths and allergy: the example of tropomyosin. Trends Parasitol 24(6): 272-278.

66. Moneo I, Caballero ML, González Muñoz M, Rodríguez Mahillo AI, Rodríguez Perez R, et al. (2005) Isolation of a heat-resistant allergen from the fish parasite Anisakis simplex. Parasitol Res 96(5): 285-289.

67. Weiler CR (2007) Anisakis simplex and cross-reacting antigens. Int J Dermatol 46(2): 224-225.

68. Tejada M, Olivares F, de las Heras C, Careche M, Solas MT, et al. (2015) Antigenicity of Anisakis simplex (s.s.) $\mathrm{L}_{3}$ in parasitized fish after heating conditions used in the canning processing. J Sci Food Agric 95(5): 922927.

69. Kobayashi Y, Ishizaki S, Shimakura K, Nagashima Y, Shiomi K (2007) Molecular cloning and expression of two new allergens from Anisakis simplex. Parasitol Res 100(6): 1233-1241.

70. Pérez Pérez J, Fernández Caldas E, Marañón F, Sastre J, Bernal ML, et al. (2000) Molecular cloning of paramyosin, a new allergen of Anisakis simplex. Int Arch Allergy Immunol 123(2): 120-129.

71. Asturias JA, Eraso E, Martinez A (2000a) Cloning and high-level expression in Escherichia coli of an Anisakis simplex tropomyosin isoform. Mol Biochem Parasitol 108(2): 263-267.

72. Asturias JA, Eraso E, Moneo I, Martínez A (2000b) Is tropomyosin an allergen in Anisakis? Allergy 55(9): 898-899.

73. Lopata AL, O’hehir RE, Lehrer SB (2010) Shellfish allergy. Clin Exp Allergy 40(6): 850-858.

74. Sereda MJ, Hartmann S, Lucius R (2008) Helminths and allergy: the example of tropomyosin. Trends Parasitol 24(6): 272-278.
75. Caballero ML, Moneo I (2004) Several allergens from Anisakis simplex are highly resistant to heat and pepsin treatments. Parasitol Res 93(3): 248-251.

76. Kobayashi Y, Kakemoto S, Shimakura K, Shiomi K (2015) Molecular cloning and expression of a new major allergen, Ani s 14, from Anisakis simplex. J Food Hyg Soc Japan 56(5): 194-199.

77. Kobayashi Y, Shimakura K, Ishizaki S, Nagashima Y, Shiomi K (2007) Purification and cDNA cloning of a new heat-stable allergen from Anisakis simplex. Mol Biochem Parasitol 155(2): 138-145.

78. Podolska M, Pawlikowski B, Nadolna Ałtyn K, Pawlak J, Komar Szymczak $\mathrm{K}$, et al. (2019) How effective is freezing at killing Anisakis simplex, Pseudoterranova krabbei, and P. decipiens larvae? An experimental evaluation of time-temperature conditions. Parasitol Res 118(7): 21392147.

79. Rodríguez E, Anadón AM, García Bodas E, Romarís F, Iglesias R, et al. (2008) Novel sequences and epitopes of diagnostic value derived from the Anisakis simplex Ani s 7 major allergen. Allergy 63(2): 219-225.

80. Anadón AM, Romarís F, Escalante M, Rodríguez E, Gárate T, et al. (2009) The Anisakis simplex Ani s 7 major allergen as an indicator of true Anisakis infections. Clin Exp Immunol 156(3): 471-478.

81. Rodriguez Perez R, Moneo I, Rodriguez Mahillo A, Caballero ML (2008) Cloning and expression of Ani s 9, a new Anisakis simplex allergen. Mol Biochem Parasitol 159(2): 92-97.

82. Łopieńska Biernat E, Stryiński R, Polak I, Pawlikowski B, Pawlak J, et al. (2020) Effect of freezing on the metabolic status of L3 larvae of Anisakis simplex (s. s.). Infect Genet Evol 82: 104312.

83. Cho MK, Park MK, Kang SA, Caballero ML, Perez-Pinar T, et al. (2014) Allergenicity of two Anisakis simplex allergens evaluated in vivo using an experimental mouse model. Exp Parasitol 146: 71-77.

84. González-Fernández J, Daschner A, Nieuwenhuizen NE, Lopata AL, Frutos CD, et al. (2015) Haemoglobin, a new major allergen of Anisakis simplex. Int J Parasitol 45(6): 399-407.

85. European Union (2011) Commission regulation of No 1276/2011. J Eur Union 50: 39-41.

86. Sánchez Alonso I, Carballeda Sangiao N, González Muñoz M, Navas A, Arcos SC, et al. (2020) Freezing kinetic parameters influence allergenic and infective potential of Anisakis simplex L3 present in fish muscle. Food Control 118: 107373.

87. Garcia F, Blanco JG, Garcés M, Juste S, Fuentes M, et al. (2001) Freezing protects against allergy to Anisakis simplex. J Investig Allergol Clin Immunol 11(1): 49-52.

88. Tejada M, Olivares F, Hera Cdl, Careche M, Solas MT, et al. (2015) Antigenicity of Anisakis simplex (s. s.) L3 in parasitized fish after heating conditions used in the canning processing. J Sci Food Agric 95(5): 922927.

89. Audicana L, Audicana MT, Fernández de Corres L, Kennedy MW (1997) Cooking and freezing may not protect against allergenic reactions to ingested Anisakis simplex antigens in humans. Vet Rec 140(9): 235.

90. Franssen F, Gerard C, Cozma Petruţ A, Vieira Pinto M, Jambrak AR, et al. (2019) Inactivation of parasite transmission stages: Efficacy of treatments on food of animal origin. Trends Food Sci Technol 83: 114128.

91. Sánchez Alonso I, Carballeda Sangiao N, González Muñoz M, Navas A, Arcos SC, et al. (2018) Pathogenic potential of Anisakis L3 after freezing in domestic freezers. Food Control 84: 61-69.

92. Sánchez Alonso I, Carballeda Sangiao N, González Muoz M, Arcos SC, Careche M (2021) Thermal patterns of heat treated Anisakis L3-infected fishery products allow separation into low, intermediate and high risk 
groups of potential use in risk management. Food Control 124(4): 107837.

93. Nieuwenhuizen NE, Lopata AL (2014) Allergic reactions to Anisakis found in fish. Curr Allergy Asthma Rep 14(8): 455.

94. Klapper R, Carballeda Sangiao N, Kuhn T, Jensen HM, Buchmann K, et al. (2018) Anisakid infection levels in fresh and canned cod liver: Significant reduction through liver surface layer removal. Food Control 92: 17-24.

95. Sastre J, Lluch Bernal M, Quirce S, Arrieta I, Lahoz C, et al. (2000) A double-blind, placebo-controlled oral challenge study with lyophilized larvae and antigen of the fish parasite, Anisakis simplex. Allergy 55(6): 560-564.

96. De Las Vecillas L, Muñoz Cacho P, López Hoyos M, Monttecchiani V, Martínez Sernández V, et al. (2020) Analysis of Ani s 7 and Ani s 1 allergens as biomarkers of sensitization and allergy severity in human anisakiasis. Sci Rep 10(1): 11275.

97. Shigehira Y, Inomata N, Nakagawara R, Okawa T, Sawaki H, et al. (2008) A case of an allergic reaction due to Anisakis simplex after the ingestion of salted fish guts made of Sagittated calamari: allergen analysis with recombinant and purified Anisakis simplex allergens. Arerugi 59(1): 5560.

98. Iijima S, Moriyama T, Ichikawa H, Kobayashi Y, Shiomi K (2012) Case reports. Arerugī 61(8): 1104-1110.

99. Guardone L, Nucera D, Lodola LB, Tinacci L, Acutis PL, et al. (2018) Anisakis spp. larvae in different kinds of ready to eat products made of anchovies (Engraulis encrasicolus) sold in Italian supermarkets. Int J Food Microbiol 268: 10-18.

100. Brutti A, Rovere P, Cavallero S, D’Amelio S, Danesi P, et al. (2010) Inactivation of Anisakis simplex larvae in raw fish using high hydrostatic pressure treatments. Food Control 21(3): 331-333.
101. Šimat V, Trumbić Ž (2019) Viability of Anisakis spp. larvae after direct exposure to different processing media and non-thermal processing in anchovy fillets. Fishes 4(1): 19.

102. Bao M, Cipriani P, Giulietti L, Roiha IS, Paoletti M, et al. (2020) Airdried stockfish of Northeast Arctic cod do not carry viable anisakid nematodes. Food Control 116: 107322.

103. Lopez I, Pardo AM (2010) Evaluation of a real-time polymerase chain reaction (PCR) assay for detection of Anisakis simplex parasite as a food-borne allergen source in seafood products. J Agric Food Chem 58(3): 1469-1477.

104. Yang X, Nian R, Lin H, Duan C, Sui J, et al. (2013) Detection of anisakid larvae in cod fillets by UV fluorescent imaging based on principal component analysis and gray value analysis. J Food Prot 76(7): 12881292.

105. Rodríguez Mahillo AI, González Muñoz M, Heras Cdl, Tejada M, Moneo I (2010) Quantification of Anisakis simplex allergens in fresh, long-term frozen, and cooked fish muscles. Foodborne Pathog Dis 7(8): 967-973.

106. Xu X, Sui JX, Cao LM, Lin H (2010) Direct competitive enzyme-linked immunosorbent assay for rapid screening of Anisakid larvae in seafood. J Sci Food Agric 90(5): 877-881.

107. Cai XY, Wu ZG, Jiang JF (2018) Research on draft notification measures and countermeasures regarding Peru's release of canned fish parasites. China Sta (10): 20-21.

108. Fiorenza EA, Wendt CA, Dobkowski KA, King TL, Pappaionou M, et al. (2020) It's a wormy world: Meta-analysis reveals several decades of change in the global abundance of the parasitic nematodes Anisakis spp. and Pseudoterranova spp. in marine fishes and invertebrates. Glob Chang Biol 26(5): 2854-2866. 